\section{Reports on Radiation Chemistry}

The United Kingdom Atomic Energy Authority Research Group has recently published selected abstracts of unclassified reports in the field of radiation chemistry and a bibliography of the published literature up to February 1957, compiled by R. W. Clarke (pp. iv +209 . A.E.R.E. C/R 1575 . Parts 1-6. Supplement 1. London: H.M. Stationery Office, 1957. 28s. net). This publication contains 877 references and is divided into six sections, dealing with water and aqueous inorganic systems; organic compounds ; gaseous systems ; solid systems ; biochemistry and radiobiology; and miscellaneous, including colloids, applications of radiation and general reviews. Author and subject indexes are provided. In the individual sections, report abstracts are given first, followed by annotated 'open literature' references. The report references are arranged alphabetically and serially by report reference number, and the other references by author. Recent declassified American reports are included.

\section{Guide to Literature on Atomic Energy}

A HANDY booklet entitled "Guide to U.K.A.E.A. Documents", edited by J. Roland Smith (pp. 20. London : United Kingdom Atomic Energy Authority, 1958), provides a general description of the form in which information concerning the U.K. Atomic Energy Authority is published with special reference to its own publications and of their availability to the public. After explaining that the Authority consists of three Groups-Industrial, Research and Weapons Groups-and a London Office and that scientific and technical information is issued by the Groups independently, the Guide details how unclassified information is published and where unclassified documents may be obtained or consulted. Current reports are listed every month in the "U.K.A.E.A. List of Publications Available to the Public" which the Authority's library at Harwell compiles and issues free of charge. Cumulative lists are also published. Classified documents cannot be made generally available, but in certain circumstances may be accessible to industry, research and government organizations. Finally, the Guide lists and explains the various serial codes and numbering systems used by the Authority for reference to documents and reports. This will be of great value to librarians and cataloguers. For material of more general interest, for example, news of the Authority's activities, lectures delivered by members of the staffs, lists of patents, etc., attention is directed to the monthly bulletin, Atom, which is issued by the Director of Public Relations from the London Office (11 Charles Street, S.W.1).

\section{The African Pygmies}

A paper entitled "The African Pygmies", by Prof. R. Ruggles Gates, has recently appeared in Acta Geneticae, Medicae et Gemellologiae (7, 159; 1958). A detailed discussion of the early literature is given with observations on skin colour, blood groups, and skull and skeletal measurements. It concludes with theories on the origin and relationships of the African Pygmy. The early literature shows that Pygmies occupied a much wider area than at present, which included the Cameroons, Sierra Leone and probably Liberia. Accounts are given of early as well as later European contacts with the tribes. The Pygmies are of ancient origin, with mahogany skin and hairy body. The Negroes have since acquired a black skin by mutation and their bodies have become hairless. The common ancestor of both is thought to be a tall mahogany-skinned race with a hairy body, but this race may now be extinct. The dwarfing of the Pygmy is the result of a single gene mutation of the achondroplastic type. Racial mixture with the Negroes is considered. The Pygmies hunt in the forest, supplying meat to their Negro overlords, who in turn give the Pygmies bananas, this being a symbiotic relationship. However, this is fairly recent, for prior to the introduction of the banana the Pygmies probably fed themselves. Forest Negroes frequently take a Pygmy wife and the children become 'Negroes', but the reverse does not occur; consequently, the Pygmies remain pure except for occasional unofficial mixing. The $F_{1}$ hybrids are intermediate in stature and backcross to the Negroes, so becoming absorbed. Measurements show that the Pygmy skull is frequently little smaller than that of the Negro. The ranges apparently overlap, although some Pygmy skulls are very small. The Pygmy skull is very primitive and characteristic, and the Pygmy teeth and jaws are the worst in the human race. This probably has a nutritional basis.

\section{Institute of Physics}

$A_{T}$ the annual general meeting of the Institute of Physics held in London on July 1, Sir George Thomson (master of Corpus Christi College, Cambridge) was elected president. Dr. R. W. Sillars was elected a vice-president; Dr. J. Taylor, honorary treasurer; and Prof. F. A. Vick, honorary secretary. The two new ordinary members of the Board elected were Dr. A. C. Menzies and Dr. J. Topping. Sir Lawrence Bragg (resident professor and director of the Davy Faraday Laboratory of the Royal Institution) was elected to honorary fellowship in recognition of his eminent work and valuable contributions to know. ledge in the field of physics.

\section{Royal Meteorological Society : Officers for 1958-59}

THE following were recently elected to office in the Royal Meteorological Society : President, Prof. P. A. Sheppard; Vice-Presidents, Dr. A. W. Brewer, Dr. H. L. Penman, Dr. C. H. B. Priestley and Dr. R. C. Sutcliffe; Vice-President for Canada, Mr. R. C. Graham; Vice-President for Scotland, Mr. J. R. Atkinson; Treasurer, Mr. B. C. V. Oddie; Secretaries, Mr. P. J. Meade, Dr. R. S. Scorer, Mr. J. S. Sawyer (Editor), Dr. A. G. Forsdyke (Librarian).

\section{All-India Congress of Zoology}

The Zoological Society of India is organizing the first All-India Congress of Zoology at Calcutta during Oetober 31-November 6. It is the first time that an attempt has been made in India to hold such a conference and to bring together all the zoologists of the country. A number of delegates from foreign countries are expected to attend. The last date for submission of papers to be read before the Congress is August 15. Further information can be obtained from Dr. B. S. Chauhan, Zoological Society of India, 34 Chittaranjan Avenue, Calcutta 12.

\section{The Royal Society and the Nuffield Foundation Commonwealth Bursaries}

Awards under the Royal Society and Nuffield Foundation Commonwealth Bursaries Scheme have been announced as follows: Prof. G. M. Badger, 